\title{
China-Arab Cross-Civilization Exchange and the Construction of the Community of Destiny
}

\author{
Ying-jun Gou \\ School of foreign languages \\ University of Jinan \\ Jinan, China
}

\begin{abstract}
Cross-civilization communication is the concrete process of civilization dialogue, and dialogue civilization is the fruit of civilization exchange. Nowadays, exchanges and dialogues of different civilizations have become the universal demand of all countries. With the advocacy of China's landing in the Middle East and the deepening of Sino-Arab civilizations dialogue, cultural openness and integration once again stimulated a more comprehensive and deeper collision and exchange of two civilizations, opening up a new model for the convergence of the two civilizations. The dialogue type civilization deepens the mutual cognition, the consultation and the cooperation, thus promotes the Sino-Arab civilization exchange and mutual learning. On this basis, the establishment of an inclusive world order, steadily advancing Belt and Road and promoting peace in the Middle East has important reference value for the construction of the Sino-Arab Community of Destiny.
\end{abstract}

Keywords-Cross-civilization exchange; Sino-Arab civilizations dialogue; Destiny Community

\section{INTRODUCTION}

Cross-civilization communication is the concrete process of civilization dialogue, and dialogue civilization is the fruitful result of civilization exchange. The exchange of Chinese civilization and Arab Islamic civilization has a long history. For thousands of years, the ancient Silk Road has been closely linked with the two major nationalities, breathing and destiny. In the long history, peace, tolerance, mutual learning, mutual benefit and win have always been the main theme of Sino-Arab friendly exchanges. Under the new situation of "harmony is the most important, harmony but difference" culture makes the two civilizations always keep mutual communication, inclusiveness, diversity, symbiosis and mutual learning. Under the new situation, the construction of "Belt and Road" is becoming the important practical platform for pushing the people of various countries in the Islamic world to construct the community of human destiny. It also opens up a new path for the dialogue between Chinese civilization and Islamic civilization, endows with new connotations and injects powerful realistic motive force into the dialogue between Chinese civilization and Islamic civilization.

This study is supported by University of Jinan (No. 17YB08)

\section{REVIEW THE MUTUAL EXCHANGE OF SINO- ARAB CIVILIZATIONS}

The ancient Silk Road witnessed the splendor of "emissaries facing the Tao and business trips through the sea". Among them, the two major civilizations have a long history of mutual exchange and mutual integration. The Silk Road recorded the history of "the development of civilization in opening up and the coexistence of nations in integration", which became the channel for exchanges between ancient Chinese and Arab civilizations.

In the Tang Dynasty, Islam was introduced into China via the land and sea Silk Road, and a large number of Arab and Persian merchants settled in China and thrived. They were mainly engaged in trade, study tours, and missionary missions, and gradually formed a number of "Fanfang" in large cities such as Chang' an, Guangzhou, and Quanzhou. They were able to set up worship temples and freely perform religious lessons in the Fanfang. [1] Diplomacy between the two sides is even more friendly exchanges, courtesy.

In the Yuan Dynasty, when the Yuan Dynasty returned to the whole world, the imperial court implemented an allinclusive religious policy. A large number of returned senior officials from the Western regions who came to China were appointed, such as the ancestor of Zhenghe, Sedanchi-Xuan Siding, who was highly regarded by the court. The Yuan Dynasty adopted the household registration system to establish the Chinese national identity of Muslims in China for the first time, and thus "Chinese Hui" was born, which is the product of the mutual integration and mutual assimilation of the Confucian civilization. Sino-Arab civilization exchanges and integration in the Yuan Dynasty has been unprecedented development.

The Ming Dynasty restored the supremacy of the Han people, and the practice of ruling the country by Confucianism, through the interpretation of the Confucian scriptures and the religious reform movement of Buddhism by Islam, also promoted the Sinicization of Islam in China. Zhenghe, a Chinese Muslim navigator, made a "journey of peace" to the Western world in the spirit of peace, openness and tolerance, and constantly expanding the space for dialogue between the two civilizations. With their religious faith in Islam and their proficiency in Arabic and Persian, Zhenghe's fleet contacted the Arab countries along the way to reduce the gap. Enhancing 
mutual understanding and further expanding the "radius of trust" is an outstanding pioneer of cultural exchanges between China and Arab. It has made great contributions to promoting the exchanges of civilization between Sino-Arab. Among them, the "Islamic factor" has become an important motivation for the dialogue between Zhenghe's fleet and the Islamic countries along the route. [2]

\section{THE INTEGRATION AND INNOVATION OF SINO- ARAB CIVILIZATION}

The core of Chinese civilization is "harmony" culture, which contains the world view of the unity of nature and man, the international view of Concord, the social view of harmony but different, and the moral view of people toward the good. The thought of "harmony" is the most vital cultural core and factor in the Chinese traditional ideology and culture.

The core value of Islamic civilization is the thought of "middle way". The middle way is the principle of peace, which is the basic idea in the Islamic doctrine and teachings. The doctrine of Islamic justice requires Muslims to always maintain correct faith, adhere to the doctrine of justice and impartiality, and points out the serious dangers of deviating from the doctrine of justice and moving to extremes, warning Muslims to guard against extremes and distances from the extreme. Therefore, the doctrine of justice is not only the doctrine of peace and harmony advocated by Islam, but also the doctrine that runs through Muslim life. [3]

The differences between the two civilizations are inevitable. The Chinese civilization is secular culture, while the Islamic civilization is religious culture. But there are commonness between them: the core of Islam is the spirit of peace, and the core of Confucian culture is the spirit of harmony but difference. Both sides are "harmony" thinking, not dualistic antagonism. [4] It is precisely because of this that the fusion of Chinese civilization and Islamic civilization in the past 1300 years has produced Chinese Muslims and Chinese Islam and realized the dual identity of "patriotism and religion", which is an innovation and sublimation of the monistic identity of "recognizing that the Lord is the only one".

Chinese Muslims and Chinese Islam are the product of long-term cultural collision, communication and integration of Confucian civilization. Harmony but different, all-inclusive, including tolerant to diversity is the common concept of exchanges between the two civilizations. Advocating dialogue and tolerance, respecting knowledge and encouraging learning are the important connotations of Islamic ideology. In particular, since the Ming and Qing dynasties, the Chinese Muslim sages have devoted themselves to carrying out the "interpretation of Confucianism" in Chinese, combining the idea of "middle way" in Islamic culture with "to neutralize" in traditional Chinese culture, thus promoting the Sinicization of Islam. Finally, it completed the communication and dialogue between the two languages.

\section{CULTURAL OPENING AND INTEGRATION}

In 2013, President Xi Jinping’s “Silk Road Economic Belt” and “21st Century Maritime Silk Road” strategic concept put forward new requirements for Sino-Arab cultural exchanges.
This is the first time that the Chinese civilization and the Islamic civilization have merged in an unprecedented way at the global level, which provides a historic opportunity for the Islamic civilization to walk out of the world trough, revitalize the millennium glory and move towards peace, and provide a historic opportunity for modernization.

China and Arabia countries are acquainted with each other because of the silk road. The two sides are partners in building a "one belt and one way" cooperation. Peaceful cooperation, openness, tolerance, mutual learning and mutual benefit as well as a spirit of silk road are the foundation of Sino-Arab cooperation. Over the past five years, with the maturity of the top-level design between China and Arab, it has strengthened the political mutual trust between China and Islamic countries, thus opening a new journey for dialogue and exchange and mutual learning between Chinese civilization and Islamic civilization.

The concept of "Dialogue Civilization" was first put forward by Du Weiming [5]. He believed that strengthening the dialogue among different cultures, religions and countries and regions is the most basic and the most important choice to deal with the plight of mankind. The essence of dialogue civilization is the equal exchange between various civilizations, listening to each other and learning from each other. In the process of equal communication, dialogue and communication, we reach the cross-cultural consensus, and finally create a series of rules for peaceful coexistence and mutual learning, and form a world civilization that transcends nations and nations. The pursuit of peaceful global civilization is the ultimate goal of the integration of Chinese and Arab civilizations. This vision is highly compatible with the Confucian spirit of Chinese civilization and the core values of Islamic civilization. It is also the common ground and meeting point of promoting the common feelings of the Chinese and Arab peoples. With China's initiative to land in the Middle East, Sino-Arab civilization dialogue has been deepening and cultural exchanges have become more and more extensive. Both sides rely on the China-Arab Cooperation Forum to actively carry out various forms of cultural exchanges, promote mutual learning between civilizations, and help the people to communicate with each other.

However, both civilizations are also facing difficulties. In the process of fusion of traditional culture and modernization, the collision between religious tradition and secularization will run through the whole process of civilization development. The "Islam factor" plays a leading role in the political, economic, cultural and other aspects of the Arab countries, and it also restricts people's world outlook, values and social outlook. Therefore, deepening folk exchanges in the religious field plays a vital role in increasing the radius of mutual trust between the two peoples.

Beginning in 2012, the Chinese Academy of Social Sciences and the Organization of Islamic Cooperation held three consecutive seminars on China and Islamic Civilization. Through joint discussions, the two sides are devoted to revealing the unknown history of exchanges between China and the Islamic world, showing the breadth and depth of the exchanges between the two sides, and discussing the 
significance of the ancient exchanges to the contemporary exchanges. To some extent, this kind of equality, mutual benefit, win-win, learning from history, looking forward to the future of the interactive exchange reflects the different civilizations, different religions and different social systems.

People-to-people exchange is an important pillar for China and Arab countries to build Belt and Road, and civilization dialogue is an important support for promoting the exchange, meeting and blending of Chinese civilization and Islamic civilization. In today's multicultural era, the development of Chinese civilization and Islamic civilization is once again at a crucial historical node. With its concept of openness, tolerance and harmony, the Chinese civilization actively deepens dialogue with civilizations of all countries in the world, so that their respective civilizations can adapt to each other, and grow each other in the course of exchange and mutual learning, and abandon their prejudices and develop together. To build a worldwide dialogue civilization and forge a new inclusive world order based on the community of human destiny.[6] Therefore, cultural openness and integration will be a successful model for cross-civilization exchanges and dialogue between China and Arab. Through exchanges and dialogues among civilizations, they will learn from each other, inherit and carry forward the spirit of the ancient Silk Road, and promote people-to-people exchanges through high-level exchanges.

\section{CONCLUSION}

Join hands to build a Community of fate between China and Arab

The "Belt and Road" initiative provides China and Arab with a platform for mutual discussion, construction and sharing, offers a useful reference for the common prosperity among countries and the development and expansion of regional cooperation, and highlights the trend of the times of peace, development, cooperation and win-win cooperation. The opportunity for each country to share in development is the understanding of "harmony" in traditional Chinese culture and the support of Sino-Arab cooperation. Facing the future, under the initiative of "Belt and Road", China will continue to "look west", and Arab countries will continue to "go east" along the sea and land Silk Road[7]. Chinese Dream, the great rejuvenation of the Chinese nation, is highly compatible with the Arab countries' ideal of seeking prosperity and national rejuvenation. Guided by the concept of openness, mutual benefit, mutual benefit and win-win situation, China and Arab countries jointly promote the construction of "Belt and Road" and work hand in hand to build a new type of international relations and destiny community.

\section{ACKNOWLEDGMENT}

This study is supported by University of Jinan (No. 17YB08)

\section{REFERENCES}

[1] J. Ding, “On the intercommunion of the people's hearts between China and Islamic countries,” Arab World Studies, No.3, pp, 61-64, May 2016. (In Chinese).

[2] L.R.Ma, "Comparative advantage of China's Silk Road Strategy and Islamic Silk Road Human Exchange,” The world religious culture, vol. 1, pp, 27-29, 2015. (In Chinese) .

[3] Arab Human Development Report 2016, Regional Bureau for Arab States, United Nations Development Programme, P 13, http://www.arabhdr.org/reports/2016/english/ExecutiveENG.pdf.

[4] J.Y.Fang, "The blending of Civilization: an opportunity for the Modernization of the Islamic World,” Journal of the central institute of socialism, vol. 5, pp, 40-42, Oct. 2017. (In Chinese).

[5] W.M. Du, “The latest path and concrete actions of Dialogue among Civilizations,” The open era, vol.1, 2007. (In Chinese).

[6] W.S. Jia, "Cross-civilization Communication, Dialogue Civilization and the Construction of the Community of Human Destiny,” Journal of Renmin University of China, Beijing, vol, 5, 2017. (In Chinese).

[7] M.Wang, "China's Middle East diplomacy from the Perspective of Belt and Road: inheritance and responsibility" http:// www.yidianzixun.com, July 2018. (In Chinese). 